\title{
Responsibility experience for your own life through volunteering
}

\author{
Vida Gudzinskiene ${ }^{1, *}$ and Neringa Kurapkaitiene ${ }^{1}$ \\ ${ }^{1}$ Mykolas Romeris University, Vilnius, Lithuania
}

\begin{abstract}
Phenomenon of the Volunteering reveals itself through dedicated time for volunteering, duration of volunteering commitment, area where volunteering is implemented and through age group of the volunteers. The object of the study is volunteering experience of young adults. Interpretative Phenomenological Analyses is research methodology. According to the phenomenological approach, research itself is not focusing on any foreseen objectives, oriented to the volunteers' experience. In this article is presented part of the research, giving deeper view on one of the super-ordinates theme, with the aim: to present responsibility for your own life experience of young adults in long term and full-time volunteering, while volunteered is held in social help area. In the study participated 6 research participants, 3 young men and 3 young women, 20-30 years old. To collect the data of the research were used semi-structured interviews. Conclusions of the study presented in this article shows 1) that through volunteering experience research participants perceived power and duty of own life's quality. They got awareness about their own life - they can and they must be responsible of own life. 2) This power of responsibility is hidden in themselves and change of own life depends on the decisions made by them while volunteering. Prior experience of responsibility is opening decision possibilities and freedom possibilities in any change of life.
\end{abstract}

Key words - volunteering, responsibility experience for you own life, interpretative phenomenological analyses.

\section{Introduction}

Long term volunteering is when volunteering duration is longer than 2 months and the volunteer is directly involved into the organization of daily life. Volunteers in long term volunteering are involved into dynamics of diverse relations of clients, organization staff and other volunteers. Volunteers are often invited to commit to daily communion. In Lithuania, as in other countries, there is very little research on volunteering based on subjective experience. This can be attributed to the qualitative research field, which is still new, as well as to the field of research, which is broad and multi-layered. International researchers emphasize that the experience of volunteering varies depending on the field of volunteering and the form of volunteering. Form of volunteering depends on the duration of the voluntary activity. It can be part-time volunteering or full-time volunteering and creates different conditions for involvement and experience. Research defines the form of volunteering, highlights the

\footnotetext{
*Corresponding author: vida.gudzinskiene@mruni.eu
} 
difference of the studies between short-term, long-term and long-term full-time (hereinafter voluntary service) and the ambiguity of volunteering experience: learning in volunteering becomes multifaceted when volunteering in long-term voluntary service (devoting full time to volunteering) [1-3]. In 2007 the Association of Voluntary Service organizations (AVSO), which brings together international volunteers coordinating organizations and implementing long-term voluntary service, produced a review of research conducted in European countries analysing long-term voluntary service at the international level - "The impact of long-term youth voluntary service in Europe: a review of published and unpublished research studies". The review is presenting research, related to the implementation of voluntary service, volunteering learning and the benefits of volunteering for volunteers [1].

The research results reveal the significance and benefits of voluntary service for volunteers. The benefits of volunteering for volunteers are also enhanced by motivational research [4], which reveals that volunteers driven by one motive, mostly values, come to volunteer and commit to volunteering for a longer period of time, driven by completely different motives - usually social adjustment, learning and solving personal problems. Priorities of the motivation reveal the potentiality of young adults for volunteering as a learning environment and raise the question of educology about learning in the volunteering. Long-term voluntary service creates a conductive environment for learning, encourages volunteers to grow strengthens their independence, confidence, self-esteem; creativity and maturity; growth of cultural awareness, etc. [5-16].

It should be noted that many studies are carried out without defining all the characteristics of a particular volunteering experience and then the result can be unequally assessed and analysed. The paradigm of learning in volunteering is also spread in research, but how volunteering is seen by the volunteers themselves is lacking in research and remains unanswered how do volunteers evaluate volunteering, which is a place of learning?

The object of the study- Experiences of young adults volunteering

The question of the research - how do young adults experience long-term and full-time volunteering in the field of social aid? This article represents one aspect of the research experience of responsibility for one's own life of young adults through volunteering.

The aim of the research is to reveal the phenomenon of young adults' experience of taking responsibility for their own lives in long-term and intensive volunteering.

\section{Methodology and research participants}

In order to carry out a phenomenological study, we have focused on intensive and continuous methodological approach, retrospective self-reflection, in terms of personal volunteering experience, and reflection on the research conducted. Research design based on Interpretative Phenomenological Analysis (IPA), where the main purpose of the IPA is not only to reveal unique meaning in life of the participant (phenomenological part), but also to the content and multilayer (interpretative part) that is not always visible [17]. IPA is an ideological posture based on a certain phenomenon in a particular context. Moreover, IPA is conducted with a small group of study participants. "The lever of subjective interpretation is the analysis of the author's idea. It ensures the unity of the whole study: in every study there is an "inner core" where all thoughts of the author evolve" [17]. The role of the IPA researcher is to understand how the participants of the research are trying to perceive their experience. Steps of Interpretative Phenomenological Analysis: Multiple reading - Phenomenological comments - Interpretative comments - Topics - Clusters (of a participant) - Topic clusters (of several participants) - Meta-themes. It is important to note that the IPA study is primarily a creative research and reliability should not limit the creativity of the researcher, but on the contrary, it should be broad enough to allow the researcher to accomplish a creative and systematic study 
and to provide data [17]. The IPA primarily focus on the phenomenological experience of the research participants, seek to understand the perception of the experience by analysing and naming frustrating topics, clusters, topic clusters and meta-themes. Only after the analysis of the participants' experience through volunteering in the discussion part is made, another step of interpreting the analysis of the participants' experience through learning perspective can be taken.

Considering the saturation of the study and J. A. Smith's [17] recommendation to limit the study to a small number of study participants, in the research participated 6 ex-volunteers -3 young women and young 3 men in the age frame 20-30 years. Selecting the research participants, in the IPA methodology, it is recommended to ensure the homogeneity and diversity of the research participants. Homogeneity of the research participants was insured with age frame - all research participants participated in the voluntary activity when they were young adults (18-30 years old) and participated in the study interview while they were still in the same age group. Homogeneity is ensured also by the area of volunteering - social help area and time given for volunteering - long term and full-time volunteering. The research participants were volunteering not less than 20 hours a week and, during the volunteering, they had no additional activities, such as study or work, it means volunteering was the main activity for them at this particular time. Duration of volunteering was no shorter than 6 months. All these criteria insure that research participants had enough similar experience, which is suitable for the interpretation and analyses in the IPA research. In highlighting the diversity aspects of the research participants, it should be noted that ex-volunteers are not concentrated in one living or volunteering area, they are of different genders, different ages, different volunteering countries, and different organizations. It ensures that the integrity of their experiences is only defined by the experience of volunteering, which is homogeneous according to the requirements of the research. The age of the research participants during volunteering and during the research is represented in Table 1 below.

Table 1. Age of research participants during volunteering and during participation in the interview.

\begin{tabular}{|l|l|l|l|l|}
\hline $\begin{array}{l}\text { Research } \\
\text { participant }\end{array}$ & $\begin{array}{l}\text { Age at the be- } \\
\text { ginning of the } \\
\text { volunteering }\end{array}$ & $\begin{array}{l}\text { Age at the end of } \\
\text { the volunteering }\end{array}$ & $\begin{array}{l}\text { Duration of the } \\
\text { volunteering }\end{array}$ & $\begin{array}{l}\text { Age during the } \\
\text { participation } \\
\text { in the research }\end{array}$ \\
\hline 1 woman & 22 years & 23 years & 12 months & 25 years \\
\hline 1 woman & 22 years & 23 years & 12 months & 26 years \\
\hline 1 woman & 25 years & 25 years & 6 months & 27 years \\
\hline 1 man & 19 years & 20 years & 9 months & 21 years \\
\hline 1 man & 25 years & 25 years & 6 months & 26 years \\
\hline 1 man & 23 years & 24 years & 16 months & 29 years \\
\hline
\end{tabular}

According to the IPA methodology [17], participation in the research is voluntary. All the participants were invited through organizations, responsible for coordinating volunteers, and voluntary service programs. The volunteering process of the research participants has been experienced in the past, i.e. retrospective experience gained through European Voluntary Service program (4 study participants), through the Voluntary Service for Young People: action programme (1 study participant) and through the International Voluntary Service Programme created by the Point Coeur Organization (1 study participant). As projected, the minimum duration is 6 months, with a maximum duration of 16 months. All the participants of the research did volunteering in the area of social assistance; their experience was based on communication and social assistance for the recipients. The duration of the volunteering and dedicated hours per week for volunteering are represented in the Table 2 below. 
Table 2. Duration and dedicated hours per week for volunteering of the research participants.

\begin{tabular}{|l|l|l|l|}
\hline $\begin{array}{l}\text { Research } \\
\text { participant }\end{array}$ & Voluntary Service Programme & $\begin{array}{l}\text { Dedicated hours per } \\
\text { week for volunteering }\end{array}$ & $\begin{array}{l}\text { Duration of } \\
\text { volunteering }\end{array}$ \\
\hline 1 woman & European Voluntary Service & 30 & 12 months \\
\hline 1 woman & European Voluntary Service & 30 & 12 months \\
\hline 1 woman & Youth Voluntary Service & 20 & 6 months \\
\hline 1 man & European Voluntary Service & 30 & 9 months \\
\hline 1 man & European Voluntary Service & 30 & 6 months \\
\hline 1 man & Point Coeur & 40 & 14 months \\
\hline
\end{tabular}

The study adopts in-depth, semi-structured interviews, based on the recommendations of Smith [17] - questions are open-ended and broad, so that the participants could share their views and individual experiences without any limitations. During the interview, the questions about learning were not raised. Any direct questions about learning - could prevent an authentic participant's view on volunteering experience and project an unconscious attempt to meet the imaginary or heard requirement - what should have been learnt; this leads to replicate and "template" outcomes of learning. Smith [17] enables the researcher to look for indirect questions, related to the research issue, and to discover questions that lead to revealing deep and authentic experiences. Volunteering requires entering new environment, meeting new people and engaging in new activities, all of that becomes a way of inevitably spontaneous learning for young adults. It leads to a presumption that any experience through volunteering could phenomenologically be recognized as a learning experience.

Transcription of the research interviews and narrative of the research participants is quoted with these signs:

[ ] - part of quotation is removed seeking to reveal main though of the research participant;

(...) - with multipoint in quotation we mark pauses, up to 7 seconds and indicated in square brackets;

(silence) - is remarked, when pause is longer than 7 seconds;

( ) - in brackets, we describe notes connected to the behaviour of the research participant;

(Saule, 123) - at the end of the quotation we write the name (changed) of the research participant and the number of the line in the interview;

bold - strong and laud pronounced word or phrase during interview.

The quotes of the research participants are written in italic.

\section{The results of research and analysis}

After data analysis of the in-depth interviews, one of the important findings is the experience of the Responsibility for your own life through volunteering. The meta-theme of responsibility for your one own life unfolds through two themes - "You should not do anything you do not want to be accountable for" and the value of nuggets and morsels of life (Fig. 1).

The responsibility experienced by the research participants in volunteering is unambiguously related to the perspective of personal life after volunteering and continues with personal commitments and recognition of the value of life. Thus, according to one participant, the first topic of the meta-theme "Responsibility for your life" is: "You should not do anything you do not want to be accountable for" ....

In volunteering, free chosen responsibilities presuppose volunteers' ability to take full responsibility for own actions and decisions. They realize importance not to escape the situations, in which they find difficult for themselves: "There is a project assigned to it, and since 


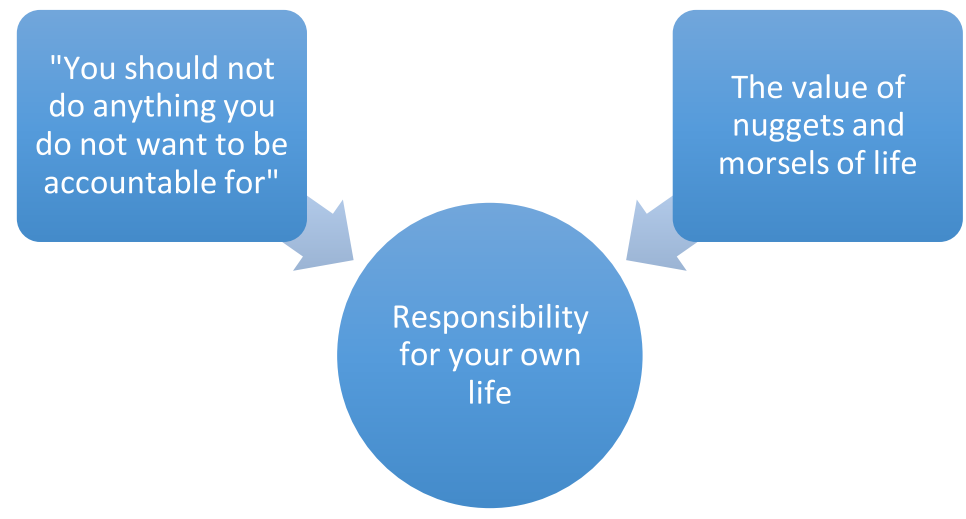

Figure 1. The meta-theme "Responsibility for your own life.

this evees (the European Voluntary Service program) is once in a lifetime, it's like feeling such a responsibility that you just can't betray those from this organization (Karolina, 311-313); "No (...) probably there were no thoughts out there to quit, because it was hard, because I disagreed with something, because not everything was going well (Ieva, 104-105).

The desire to transfer responsibility to others, especially in difficult situations of volunteering, did not disappear, but the participants of the study gained more awareness to realize this desire and not give in to it: "there were also moments where you know (...) I say it was important somehow when I was already (...) was at fault, you know, those consequences to take, those that are important in your life, in general. And I'm proud to have been able to, because I think it should get better that way. In that sense (...), you shouldn't do what you're then afraid to take responsibility for (Eimantas, 566-570); [...] this experience gives me the courage to take responsibility (Ieva, 306-307). Eimantas, Ieva and other research participants, realizing their responsibility, felt pride, freedom and power to be the masters of their lives: It was like that before I left - it seems to be nothing here to do and ..mmm... here is not my responsibility, here is like I say. And when I returned (after volunteering - author's note), just about everything changed a lot and gave a lot of quality to life. And it seems to me anyway is that, how to say, valuable experience (...) (Ieva, 96-98). Indirectly naming, talking about their choice to be responsible, research participants sought to create and think the way they wanted to create around them: Here's a very interesting thing about how you see a situation, when you see a bad situation, the situation is bad and is (...), but if you see well, you look from another angle and you start to see those good situations, it's those bad situations out there, you them see less. You know that such situations exist and in that sense it helps you to grow as a person (Kestas, 317-320); It was very nice for me and I then wondered - why I don't do this, why let's say the inhabitants of the staircase of our house, they never talk, why not do a picnic in the yard, let's say snacks or something like that in the yard.(Karolina, 280-283). Research participants returned to themselves, realizing that the responsibility for life does not depend on others, but on themselves.

Another theme of the meta-theme "Responsibility for Your Life" is the value of the nuggets and morsels of life. The important details in the life of the research participants became apparent when they left daily life far away and felt their lack while volunteering: Evaluating maybe somehow, well I dreamed of some things, maybe when I could drive a car, I missed it, I lacked such perfume (laughs), I don't know perfume (laughing), but really very very much like that, my mum sent a parcel to Peru as well, then I gave those perfumes to 
others, but in that sense, the little details of the life before are so fantastic! (Eimantas, 662666). Although the things Eimantas left were not important to him before he volunteered, they became important by living without them. Driving a car, perfume was an imperceptible Eimantas' daily life before volunteering, but as the daily life changed, the pleasing details gained a special meaning, becoming "fantastic" symbols. The reflection of the routine before volunteering began with a sense of lack of the usual details when volunteering. The remembrance of the details revealed retrospectively Eimantas' attachment to them and the joy he provided, which the young man had not noticed before volunteering.

After volunteering, research participants refined what is similarly important and what they want to nurture further: "actually, in free time I'm reading, in the sense of reading and, if possible, adapting to the things I read and in fact very that very much adds [...] (Kestas, 388-389); all the photos I took while volunteering disappeared because my computer fell off a chair and his hard drive crashed. [...] But (...) but for a moment I somehow didn't want to cry there because of that too [...] and maybe, as they say, we need to leave the past in the past and be now, it's probably such a very physical lesson here, well that's the way it is (Ieva, 289290, 294-296 ); Well in that sense, you know, it allowed, aftercoming back (smiles) $m$ n you know to jump into my sea, in which we live as well. Just that we often don't get it anymore. [...] Well, you know, to come back and be afraid to think again (...) because here, no matter how bad and safe, more or less in Lithuania is very safe [...]. You can make money you can, you can (inspire) live without being afraid, that someone will rob you, somehow like this" (Eimantas, 668-670, 672-674, 676-677). Valuable nuggets were purified by the research participants after volunteering, on the one hand and extended the important things found in volunteering, which were highlighted by their lack in the volunteering environment - safety, earning power, convenience and other former usual amenities. On the other hand, research participants decided to nurture what they discovered through volunteering - reading, leaving the past in the past. The appreciation of morsels and nuggets in volunteering did not seem to create anything new in their lives, but an overestimated past routine gained new accents through which former volunteers create the present life.

Discussing the Responsibility for own Your Life meta-theme focuses on the unpublished decision of the research participants to change the vector of everyday life from a waiting and unsatisfying environment to those who create themselves and their environment like they want to live. The transformation that has taken place in volunteering from reactive to proactive attitudes marks a learning that has "turned" the lives of volunteers during the volunteering and after it into not complaining persons about their own lives, and to creating life by themselves. Without the opportunity to escape from situations experienced in volunteering, research participants reflect on and perceive the experience of being fully in life situations as an essential experience of maturity. Research participants transform the perceived experience into everyday life after volunteering. The inner attitude of cherishing, valuing, and being responsible is strengthened by their continued choice, no matter where they are, to shape their lives in the way, they want to live.

The experience of the research participants shows that after complicated situations and relationships during long-term volunteering, they learned to take responsibility not only for volunteering. Non-imposed but freely chosen responsibilities, even when volunteers were dissatisfied with the volunteering process, allowed them to expand their responsibilities for the whole life and personal choices. We can generalise that during volunteering can be perceived the power and duty of every volunteer to be responsible for their quality of own life. Young adults realize that they can and must take responsibility for their own lives, that only they have the power to choose approach, giving priority to their personal responsibility for life decisions. 


\section{Discussion: Linking the experiences of research participants to relevant theories in search of answers to a research question}

Considering how the research data can relate to the prevailing theories and research itself, it was important not to leave behind the experiences of the research participants, but to bring them together with the theories and other researchers into an equal relationship. Theories and researches were accumulated during the research period until the end of the research analysis without analysing them, but postponing interest in them until the research analysis was completed. After the analysis of the research data, was found the literature corresponding to the research data, which would at least partially discuss the results of the research.

According to Jovaiša [18], responsibility is the most common moral trait of a personality, motivating diligent activity in the performance of duties. Responsibility is the observance of moral, official, and juridical requirements: personal, collective, juridical responsibility. Accountability is educated by demanding accountability for one's actions. It is the most important characteristic of a person's moral maturity. Janušauskaite [19], investigating responsibility, points to freedom, justice, and guilt. Responsibility as a category of basic ethics is examined by Jaffey [20], who points out that this category of ethics defines a person's relationship to moral obligation, when human actions correspond to a conscious duty. Responsibility manifests itself in the consequences for the subject of his or her own or others 'behaviour' [21].

The essential difference between volunteering and other activities in which young adults choose to participate is experiencing a sense of responsibility and taking responsibility for the activity [22]. The sense of responsibility experienced by the research participants was associated with the relationship of trust they experienced. Those who experienced the closest relationship with employees took the most responsibility for the employees. Those who experienced the closest relationship with the help receivers took the responsibility for them. Schwartz and Howard [23], researching the link between responsibilities and volunteering, found that responsibility increases rapidly in volunteering and remains very high even after years. In addition, understanding the consequences of behaviour in volunteering experience is more adequate than not having it. Dutta-Bergman [24] wrote of the strong and complementary coexistence of individualism and community in volunteering, which stems from a unique sense of personal effectiveness and selfishness. This coexistence leads to individual social engagement. Actions that integrate the volunteers in to their lifestyle are combined with points of intersection focused on individuality and community. From them arises the definition of a life based on a responsible lifestyle. Although these studies have revealed a strong link between volunteering with responsibility or even responsible lifestyle choices, they do not analyse the process of origin of responsibility in volunteering. The origins of responsibility, revealed in the experience of the research participants, are related to the concepts of inter-subjectivity and becoming who you are defined by the relational theory. Through the interdependence of people, Elias [25] explains the interlacement of human actions and experiences. "Through the abundance of invisible chains connected to other people, a figuration is created. Many people who, according to their elementary understanding, interdependence, and reliance are interconnected in different ways and by interdependence creating figuration" [25]. Being so interdependent, people create each other. Here mentioned interdependence is invisible but as real "as every different person" [25]. A sense of responsibility and taken responsibility for an activity of the research participants expressed the nature of responsibility through a relationship with the Other, in front of which young adult becomes responsible for that relationship with the Other [26]. 
Theory argues that learning is and can be inter-subjective, relative, and arising from an interpersonal relationship [27]. Such an experience of taking responsibility for research participants' own life is based on Buber's dialogue Between, which takes place by moving away from individualism and not into collectivism, but in a dialogue between two people. The relations of the research participants in volunteering were experienced dialogically, seeing the person and associating themselves with the person, and thus increase experience of a constant interplay as ignorance, uncertainty, but at the same time as devotion and trust. Thus, the relational experience of volunteering opened up the perspective of learning through a relationship to the research participants.

\section{Conclusions}

1. Research data revealed that volunteers experienced difficult situations and relationships during long-term volunteering, learned to take responsibility not only for volunteering but also for own life. Non-imposed but freely chosen responsibilities, even when volunteers were dissatisfied with the volunteering process, allowed them to expand their responsibilities for the whole life and personal choices.

2. In volunteering, every volunteer can perceive the power and duty to be responsible for own quality of life. Research participants realize that they can and must take responsibility for their own lives, giving priority to their personal responsibility for life decisions.

3. The nature of responsibility is revealed in volunteering through a relationship with the Other, in front of which young adult becomes responsible for that relationship with the Other. The Other can be the worker of the organisation, whom volunteers are helping or the help receiver, who receives the help from the volunteers. In any case, important is relation through which volunteers feels responsible.

4. During the volunteering, in the newly perceived everyday experiences of the research participants, young adults realised how they can take responsibility and create the life they want. They increase believe and trust about themselves as proactive creators of the life they want to have and to live. Responsibility experience caused research participants from one side to take responsibility for own life, but from other side to take steps also creating life of neighbours as a figuration process.

\section{References}

[1] S. Powell, E. Bratovi'c, The impact of long-term youth voluntary service in Europe: a review of published and unpublished research studies, AVSO, Brussels (2007)

[2] M. Santinello, F. Cristini, A. Vieno, L. Scacchi, "Volunteering by chance" to promote civic responsibility and civic engagement: does it work? Journal of Prevention and Intervention in the Community 40(1), 64-79 (2012)

[3] Ö. Senyuva, European Volunary Servive - Competences for Employabilty, EVS C4E Full Survey Report (2014)

[4] E.G. Clary, M. Snyder, A.A. Stukas, Volunteers' motivations: Finding from a national survey. Nonprofit and Voluntary Sector Quarterly 25, 485-505 (1996)

[5] Structure of Operational Support EVS: The hosting organizations' perspectives. Brussels, European Voluntary Service (1999)

[6] M.S. Sherraden, J. Stringham, S.C Sow \& A.M. McBride, The forms and structure of international voluntary service. Voluntas: International Journal of Voluntary and Nonprofit Organizations 17(2), 156-173 (2006) 
[7] ECOTEC Evaluation of the European voluntary service programme, Brussels (2000)

[8] ECOTEC Mid-term evaluation of the Euromed-Youth programme, Brussels (2001)

[9] R. Evans, S. Clisby, et al. Does youth action pay? An evaluation of Action Pays (2002)

[10] Alternative-V. Experiences of international voluntary service between Eastern, SouthEastern and Western Europe, ICYE - Eastlinks Large Scale Project (2003)

[11] A.M. McBride, M. Lombe, et al. The Knowledge Base on Civic Service: Status and Directions (CSD Working Paper 03-20), St. Louis: Washington University, Center for Social Development (2003)

[12] R. Schroer. Voluntary service: Opening doors to the future, Association of Voluntary Service Organisations (AVSO, 2003)

[13] G. Birnkraut, I.E. Hein, et al. The voluntary cultural year in Germany: Perceptions of volunteers, institutions, politicians, and society - the future of civic service in the arts, Center for Social Development, Global Service Institute, George Warren Brown School of Social Work, Washington University (2004)

[14] B. Cięška, J. Ratajczak, Report on the survey of participants of EVS projects, Warsaw, Polish National Agency for the YOUTH (2004)

[15] M. Hill, D. Stevens, Volunteers who manage other volunteers and the professionalisation of volunteer management: implications for practice. Voluntary Sector Review 2(1), 107-114(8) (2011). DOI: https://doi.org/10.1332/204080511X560657

[16] V. Gudžinskienė N. Kurapkaitienè. Control relation change into trust relationship in volunteering, 7th International Interdisciplinary Scientific Conference Society. Health. Welfare 85, 1-14, Latvia (2020). DOI: 10.1051/shsconf/20208503003

[17] J.A. Smith, P. Flowers, M. Larkin, Interpretative Phenomenological Analisis, Theory, Methods and Research. Sage publication (2009), (Reprinted in 2012)

[18] L. Jovaiša, Enciklopedinis edukologiojos žodynas, Vilnius: Gimtasis odis (2007)

[19] A. Janušauskaitè, Atsakomybès ir profesinès kompetencijos svarba teisininko veikloje, (8). Moksliniu straipsniu rinkinys. "Visuomenès saugumas ir viešoji tvarka" Scientific articles 8, 119-129 (2012)

[20] P. Jaffey, Liabilities in Private Law. Legal Theory. Cambridge University Press 14(4), 233-255, 107 (2008)

[21] J. Walker, K. Crawford, Social Work and Human Development. London: Sage/Learning Matters (2014)

[22] S.H. Schwartz. Awareness of interpersonal consequences, responsibility denial, and volunteering, Journal of Personality and Social Psychology 30(1), 57-63 (1974)

[23] S.H. Schwartz, J.A. Howard. Explanations of the Moderating Effect of Responsibility Denial on the Personal Norm-Behavior Relationship. Social Psychology Quarterly 43(4), 441-446 (1980)

[24] M.J. Dutta-Bergman. Describing Volunteerism: The Theory of Unified Responsibility. Journal of Public Relations Research 16(4), 353-369 (2004), DOI: 10.1207/ s1532754xjprr16042

[25] N. Elias. Reflections on a Life. Translation (in part) from German by Edmund Jephcott of Über sich selbst; for the biographical interview (first published in Dutch in 1984) the original English manuscript was used (Cambridge: Polity Press, 1994)

[26] V. Gudžinskienė N. Kurapkaitienè. Volunteering Expression Using Different Models of Social Work with Third-Countries Citizens. Outlines of Social Innovations in 
Lithuania. Publisher: European Scientific Institute, Kocani, Republic of Macedonia, 158-178 (2013)

[27] T. Kuenkler Lernen in Beziehung. Zum Verhaeltnis zum Subjektivitaetund Relationalitaet in Lernprozessen, Transcript Verlag, Bielefeld (2011) 